\title{
Antioxidant-mediated preventative effect of Dragon-pearl tea crude polyphenol extract on reserpine-induced gastric ulcers
}

\author{
RUOKUN YI ${ }^{1 *}$, RUI WANG ${ }^{2 *}$, PENG SUN $^{2}$ and XIN ZHAO ${ }^{2}$ \\ ${ }^{1}$ Department of Food Science and Nutrition, Pusan National University, Busan 609-735, Republic of Korea; \\ ${ }^{2}$ Department of Biological and Chemical Engineering, Chongqing University of Education, Chongqing 400067, P.R. China
}

Received July 25, 2014; Accepted April 8, 2015

DOI: $10.3892 / \mathrm{etm} .2015 .2473$

\begin{abstract}
Dragon-pearl tea is a type of green tea commonly consumed in Southwest China. In the present study, the antioxidative and anti-gastric ulcer effects of Dragon-pearl tea crude polyphenols (DTCP) were determined in vitro and in vivo. Treatment with 25,50 or $100 \mu \mathrm{g} / \mathrm{ml}$ DTCP resulted in notable antioxidant effects in vitro, which manifested as 2,2-diphenyl-1-picrylhydrazyl and $\mathrm{OH}$ radical-scavenging activity. Furthermore, using an in vivo mouse model, DTCP was shown to reduce the gastric ulcer area in the stomach, in which the $200 \mathrm{mg} / \mathrm{kg}$ DTCP dose exhibited the most marked effect, with a gastric ulcer index inhibitory rate of $72.63 \%$. In addition, DTCP was demonstrated to improve stomach acidity conditions in vivo by increasing the $\mathrm{pH}$ and reducing the level of gastric juice, as compared with the reserpine-induced gastric ulcer control mice. Furthermore, DTCP altered the serum levels of a number of oxidation-related biomolecules, including superoxide dismutase (SOD), glutathione peroxidase (GSH-Px), malondialdehyde (MDA), lipid peroxidation (LPO) and catalase (CAT), to subsequently exert an anti-gastric ulcer effect. Treatment with 50, 100 and $200 \mathrm{mg} / \mathrm{kg}$ DTCP increased the SOD, GSH-Px and CAT levels and reduced the MDA and LPO levels in the mouse model of gastric ulcers. These serum level alterations resulted in the modified serum levels of prostaglandin E2 (PGE2) and nitric oxide (NO), which are associated with gastric mucosal protection. A reverse transcription-quantitative polymerase chain reaction (RT-PCR) assay is a molecular biology experiment which could determine the changes of mRNA in tissues. Using the RT-PCR assay, DTCP was observed to increase the mRNA
\end{abstract}

Correspondence to: Professor Xin Zhao, Department of Biological and Chemical Engineering, Chongqing University of Education, 9 Xuefu Road, Chongqing 400067, P.R. China

E-mail: foods@live.cn

${ }^{*}$ Contributed equally

Key words: Dragon-pearl tea, polyphenol, gastric ulcer, reserpine, antioxidant expression levels of certain genes associated with gastric ulcers: Epidermal growth factor, epidermal growth factor receptor, vascular endothelial growth factor and vascular endothelial growth factor receptor 1, while reducing gastrin expression levels. Therefore, the results indicated that DTCP induced a marked preventative effect on reserpine-induced gastric ulcers in vivo, as a result of its antioxidative capacity.

\section{Introduction}

Dragon-pearl tea is a high-quality green tea, originating from Kai County (Chongqing, China); however, the effects of Dragon-pearl tea on health have not been well characterized scientifically (1).

Green tea contains a variety of bioactive components, including theophylline, polyphenols, tannins, amino acids, vitamin $\mathrm{C}$ and minerals (2). Purine compounds in green tea, such as theophylline, caffeine and theobromine, are able to stimulate the central nervous system, enhance cognitive function and promote the secretion of gastric acid (3). An excess of gastric acid is a key cause of gastric ulcers; therefore, overconsumption of green tea may be harmful for patients with gastric ulcers by increasing gastric acid. However, black tea may help to prevent gastric ulcers (4). Through bioactive components that exert an antioxidative effect, green tea may improve the efficacy of immune function and inhibit the growth of Helicobacter pylori, which is an additional common cause of gastric ulcers (5). The effective components in green tea have not been fully characterized, and a curative effect of green tea on gastric ulcers has not been demonstrated in all cases; however, a previous study indicated that components of green tea may inhibit the development of gastric ulcers (6). A number of studies have demonstrated an association between the antioxidative effects of plant products and their preventative effect on gastric ulcers, indicating that antioxidant mechanisms may be crucially involved in the inhibitory effect of green tea components on gastric ulcers $(7,8)$. Furthermore, previous studies have indicated that the polyphenols in green tea exert an improved antioxidant effect compared with black tea (9). The present study employed a range of experimental methods to investigate the preventative effect of Dragon-pearl tea on gastric ulcers. Dragon-pearl tea crude polyphenols (DTCP) were administered to ICR mice, and the levels of a number 
of serum and stomach tissue indices of oxidation were determined in order to verify the preventative effect of DTCP on gastric ulcers in mice.

\section{Materials and methods}

DTCP extracts. A 500-g sample of Dragon-pearl tea dust was added to hot water $\left(90^{\circ} \mathrm{C}, 10\right.$ litres $)$ for $60 \mathrm{~min}$. Sodium chloride $(600 \mathrm{~g})$ was subsequently added into the extract solution to achieve a mass fraction of $6 \%$, dialyzing in distilled water for $1.5 \mathrm{~h}$. Following filtration, $15 \mathrm{~g} \mathrm{NaHSO}_{3}$ and $100 \mathrm{ml}$ aluminum sulfate saturated solution were added to the extract solution. The extract solution was heated to $80^{\circ} \mathrm{C}$ and $15 \% \mathrm{NaHCO}_{3}$ solution was added until the $\mathrm{pH}$ value of the solution reached a range of 5.0-6.0. A large quantity of precipitates was filtered and washed three times with $70^{\circ} \mathrm{C}$ water of the same volume (10 litres). The precipitates were dissolved in $\mathrm{pH} 4.0$ hydrochloric acid solution $(1.5 \mathrm{~L})$ for $50 \mathrm{~min}$, and a small quantity of gelatinous precipitate was removed by centrifugation at $25^{\circ} \mathrm{C}$ for $20 \mathrm{~min}, 4,000 \mathrm{x}$. Next, $9 \mathrm{~g} \mathrm{NaHSO}_{3}$ was added to the acid solution, which was further extracted through administration of ethyl acetate ( 0.5 times of the solution's volume) three times, with each extraction occurring for $10 \mathrm{~min}$ and the three extractions were mixed. Vitamin $\mathrm{C}$ of $2 \%$ of the tea's weight was added to water of 0.4 times the extraction's volume, and the $\mathrm{pH}$ value was adjusted to 3.0 through the addition of citric acid. The solution was washed twice with the ethyl acetate extraction, and the DTCP extracts were finally obtained using rotary evaporation (RE-52A; Shanghai Yarong Biochemical Instrument Factory, Shanghai, China).

2,2-diphenyl-1-picrylhydrazyl (DPPH) free radical assay. Samples of 4-ml DTCP solution $(25,50$ or $100 \mu \mathrm{g} / \mathrm{ml})$ were added to $1.0 \mathrm{ml}$ DPPH methanol solution $\left(1.5 \times 10^{-4} \mathrm{M}\right)$. Following storage at room temperature for $30 \mathrm{~min}$, the absorbance of the solution was determined at $520 \mathrm{~nm}$ using a spectrophotometer (UV-5100; Shanghai Metash Instruments Co. Ltd., Shanghi, China), and the remaining DPPH was quantified $\left[\left(\mathrm{OD}_{\mathrm{DPPH}^{-}}-\mathrm{OD}_{\text {sample }}\right) / \mathrm{OD}_{\mathrm{DPPH}}\right] \times 100 \%$, where OD is optical density. The results are expressed as the mean of triplicate experimental values (10).

$\mathrm{OH}$ radical assay. A 1.4-ml reaction system was constructed, containing $0.2 \mathrm{ml}$ deoxyribose $(6 \mathrm{mM}), 0.2 \mathrm{ml}$ sodium phosphate buffer solution (20 mM, pH 7.4), $0.2 \mathrm{ml}$ anhydrous iron chloride $\left(\mathrm{FeCl}_{3} ; 400 \mu \mathrm{M}\right), 0.2 \mathrm{ml} \mathrm{FeSO}$-ethylenediaminetetraacetic acid $(400 \mu \mathrm{M}), 0.2 \mathrm{ml} \mathrm{H}_{2} \mathrm{O}_{2}(3 \mathrm{mM}), 0.2 \mathrm{ml}$ ascorbic acid $(400 \mu \mathrm{M})$ and $0.2 \mathrm{ml}$ DTCP solution $(25,50$ or $100 \mu \mathrm{g} / \mathrm{ml})$. Following incubation in a water bath for $60 \mathrm{~min}$ at $37^{\circ} \mathrm{C}$, the reaction was stopped by adding $1 \mathrm{ml}$ trichloroacetic acid and $1 \mathrm{ml}$ 2-thiobarbituric acid. The solution was subsequently boiled in a water bath for $20-25 \mathrm{~min}$ at $90^{\circ} \mathrm{C}$. The absorbance was measured at $532 \mathrm{~nm}$ by ultraviolet spectrophotometer (UV-5100). All analyses were run in triplicate and average values were calculated (10).

Gastric ulcer induction. Institute for Cancer Research mice (male, $\mathrm{n}=50,7$ weeks old), purchased from Chongqing Medical University (Chongqing, China), were allocated into five groups: Normal, control and 50, 100 and $200 \mathrm{mg} / \mathrm{kg}$
DTCP ( $n=10$ per group). The mice in the normal and control groups received $0.2 \mathrm{ml}$ distilled water per day by gavage for 4 weeks. However, the DTCP group mice were orally administered 50, 100 or $200 \mathrm{mg} / \mathrm{kg}$ DTCP solutions $(0.2 \mathrm{ml})$ everyday for 4 weeks. Subsequently, the control, 50100 and $200 \mathrm{mg} / \mathrm{kg}$ DTCP group mice were administered a single intraperitoneal injection of $10 \mathrm{mg} / \mathrm{kg}$ body weight/day reserpine (Sigma-Aldrich, St. Louis, MO, USA) for 3 days. Following the final injection, all the mice were fasted for $24 \mathrm{~h}$. The mice were sacrificed using $\mathrm{CO}_{2}$ and the stomach was removed and inflated by injecting $10 \mathrm{ml}$ formalin (1\%) for $10 \mathrm{~min}$ to fix the tissue walls, and the stomach was opened along the greater curvature (11). The gastric ulcer inhibitory index of the hemorrhagic lesions developed in the stomach was measured using a D550 digital camera (Canon, Tokyo, Japan) with a square grid, and the images were analyzed using ImageJ software (National Institutes of Health, Bethesda, MD, USA). The gastric ulcer inhibitory index was calculated as follows: Inhibitory index $(\%)=($ gastric ulcer area of the control mice - gastric ulcer area of the treated mice)/gastric ulcer area of the control mice. In addition, the gastric secretion volume of each mouse was measured using a 10-ml measuring cylinder, and the $\mathrm{pH}$ of the gastric juice was measured using a SevenEasy pH meter (Mettler-Toledo Ltd., Schwerzenbach, Switzerland) following dilution 10 times with distilled water. Experiments followed a protocol approved by the Animal Ethics Committee of Chongqing Medical University (Chongqing, China).

Determination of the serum levels of superoxide dismutase (SOD), glutathione peroxidase (GSH-Px), malondialdehyde (MDA), lipid peroxidation (LPO), catalase (CAT), prostaglandin E2 (PGE2) and nitric oxide (NO). Serum levels of SOD, GSH-Px, MDA, LPO, CAT, PGE2 and NO were determined using assay kits for SOD (\#A001; WST-1 method), GSH-Px (\#A005; colorimetric method), MDA (\#A003; thiobarbituric acid method), LPO (\#A106), CAT (\#A007; visible light method), PGE2 (\#H099) and NO (\#A012; nitrate reductase method), respectively (Nanjing Jiancheng Bioengineering Institute, Jiangsu, China).

Reverse transcription-quantitative polymerase chain reaction $(R T-q P C R)$ assay. Total RNA from the gastric tissues was isolated using TRIzol ${ }^{\circledR}$ reagent (Invitrogen Life Technologies, Carlsbad, CA, USA), according to the manufacturer's instructions. The RNA was digested with RNase-free DNase (Roche Diagnostics, Basel, Switzerland) for $15 \mathrm{~min}$ at $37^{\circ} \mathrm{C}$, and purified using an RNeasy kit (Qiagen $\mathrm{GmbH}$, Hilden, Germany), according to the manufacturer's instructions. The total RNA (2 $\mu \mathrm{g})$ was incubated for $1 \mathrm{~h}$ at $37^{\circ} \mathrm{C}$ with avian myeloblastosis virus reverse transcriptase (GE Healthcare Life Sciences, Little Chalfont, UK) and random hexanucleotides to form cDNA, in accordance with the manufacturer's instructions. Primers (Thermo Fisher Scientific, Waltham, MA, USA) for epidermal growth factor (EGF; forward: 5'-GCCAAGCTCAGA AGGCTAC-3'; reverse: 5'-CAGGCCAGCCTCGTCTCAT-3'), epidermal growth factor receptor (EGFR; forward: 5'-TCGGTGCTG TGCGATTTA-3'; reverse: 5'-TTTCTGGCAGTTGCTCCT C-3'), gastrin (Gas; forward: 5'-CCTACTGCCACAACAGTT 
A

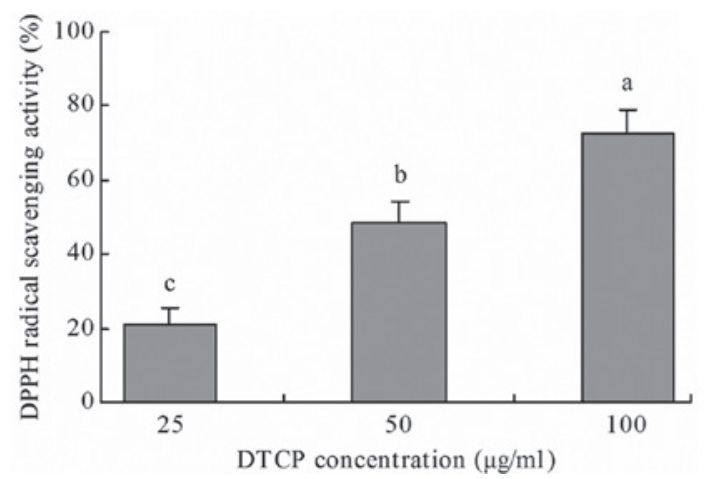

B

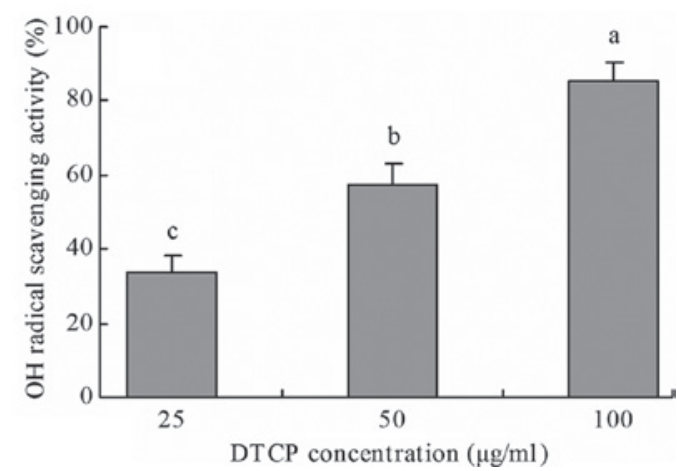

Figure 1. (A) DPPH and (B) OH free radical scavenging activity of DTCP in vitro. ${ }^{\mathrm{a}-\mathrm{P}} \mathrm{P}<0.05$ vs. the other groups, according to Duncan's multiple range test. DPPH, 2,2-diphenyl-1-picrylhydrazyl; DTCP, Dragon-pearl tea crude polyphenol.

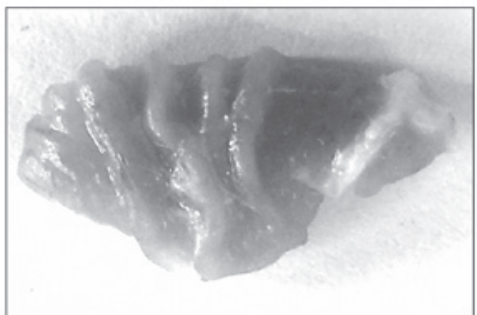

Normal

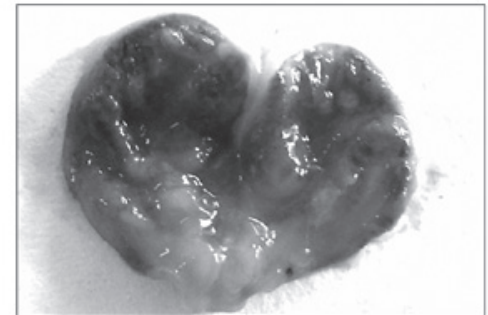

Control

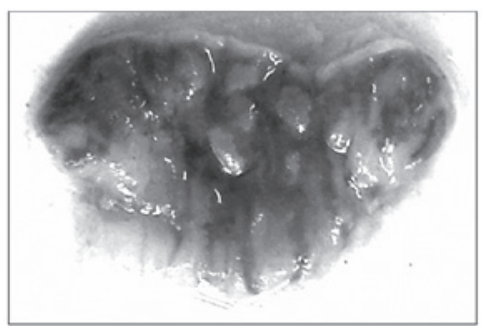

50

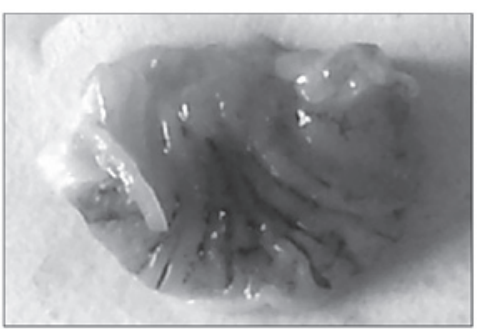

100

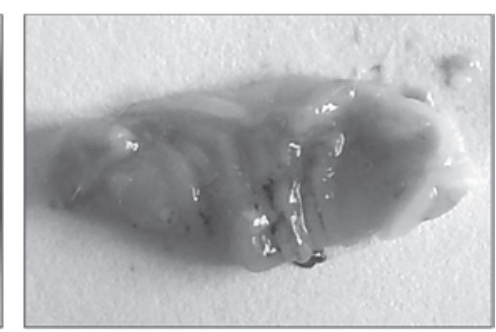

200

DTCP concentration $(\mathrm{mg} / \mathrm{kg})$

Figure 2. Stomachs with reserpine-induced gastric ulcers in mice treated with DTCP. DTCP, Dragon-pearl tea crude polyphenol.

AA-3'; reverse: 5'-CATCCATCCGTATGCTTC-3'), vascular endothelial growth factor (VEGF; forward: 5'-CCTGGC TTTACTGCTGTACCT-3'; reverse: 5'-GTGCCAAAAGGG TCATCATCTC-3') and vascular endothelial growth factor receptor 1 (Flt-1 or VEGFR-1; forward: 5'-CAAGTGGCC AGAGGCATGGAGTT-3'; reverse: 5'-GATGTAGTCTTT ACCATCCTGTTG-3') were used to specifically amplify the genes. GAPDH was used as a control (forward: 5'-CGGAGT CAACGGATTTGGTC-3'; reverse: 5'-AGCCTTCTCCAT GGTCGTGA-3'). Amplification was performed in a thermal cycler (denaturation at $94^{\circ} \mathrm{C}$ for $1 \mathrm{~min}$, annealing at $56^{\circ} \mathrm{C}$ for $1 \mathrm{~min}$ and elongation at $72^{\circ} \mathrm{C}$ for $1 \mathrm{~min}$ for 30 cycles; Eppendorf AG, Hamburg, Germany). The PCR products were separated on a $1.0 \%$ agarose gel and visualized using ethidium bromide staining (12).

Statistical analysis. Analysis of variance (ANOVA) was performed and the results are presented as the mean \pm standard deviation. Differences between the mean values of the individual groups were assessed using one-way ANOVA and Duncan's multiple range test. $\mathrm{P}<0.05$ was considered to indicate a statistically significant difference. SAS software, version 9.1 (SAS Institute, Inc., Cary, NC, USA) was used to perform all the statistical analyses.

\section{Results}

DPPH and $\mathrm{OH}$ radical scavenging activity. DTCP exhibited notable DPPH and $\mathrm{OH}$ radical-scavenging activity in vitro (Fig. 1). A DTCP concentration of $100 \mu \mathrm{g} / \mathrm{ml}$ exhibited the highest DPPH and $\mathrm{OH}$ radical scavenging activity, at 72.5 and $85.2 \%$, respectively. Furthermore, at doses of 25 and $50 \mu \mathrm{g} / \mathrm{ml}$, DTCP treatment exhibited 21.3 and $48.7 \%$ DPPH radical scavenging activity and 33.6 and $57.1 \% \mathrm{OH}$ radical scavenging activity, respectively.

Gastric ulcer levels. Gastric ulcer levels in the mice from the experimental groups were shown to decrease following DTCP treatment (Fig. 2). The gastric ulcer area was the largest in the untreated control mice at $11.47 \pm 3.13 \mathrm{~mm}^{2}$. However, the 50, 100 and $200 \mathrm{mg} / \mathrm{kg}$ DTCP-treated mice presented with reduced gastric ulcer areas of $8.68 \pm 2.66$, $6.71 \pm 1.89$ and $3.14 \pm 1.53 \mathrm{~mm}^{2}$, while the gastric ulcer levels were $24.32,41.50$ and $72.63 \%$, respectively. 
Table I. Serum SOD, GSH-Px, MDA, LPO and CAT levels in the five groups.

\begin{tabular}{|c|c|c|c|c|c|}
\hline Group & $\mathrm{SOD}(\mathrm{U} / \mathrm{ml})$ & GSH-Px (units) & $\operatorname{MDA}(\mathrm{nmol} / \mathrm{ml})$ & LPO $(\mu \mathrm{mol} / \mathrm{l})$ & CAT $(\mathrm{U} / \mathrm{ml})$ \\
\hline Normal & $189.62 \pm 23.12$ & $273.12 \pm 31.26$ & $7.62 \pm 1.37$ & $1.28 \pm 0.35$ & $17.25 \pm 3.37$ \\
\hline Control & $112.43 \pm 16.36$ & $138.28 \pm 22.18$ & $19.66 \pm 2.02$ & $9.36 \pm 1.28$ & $5.38 \pm 1.64$ \\
\hline \multicolumn{6}{|c|}{ DTCP (mg/kg) } \\
\hline 50 & $133.10 \pm 12.36$ & $177.28 \pm 19.31$ & $16.36 \pm 0.78$ & $7.08 \pm 1.13$ & $7.72 \pm 1.20$ \\
\hline 100 & $141.28 \pm 10.06$ & $209.73 \pm 21.08$ & $12.50 \pm 1.22$ & $5.27 \pm 0.49$ & $11.76 \pm 1.88$ \\
\hline 200 & $169.33 \pm 11.97$ & $238.76 \pm 18.49$ & $9.64 \pm 0.96$ & $3.08 \pm 0.29$ & $14.32 \pm 2.03$ \\
\hline
\end{tabular}

Data are presented as mean \pm standard deviation. For all measurements $\mathrm{P}<0.05$ vs. the other groups in SOD, GSH-Px and CAT values or MDA and LPO values, according to Duncan's multiple range test. SOD, superoxide dismutase; GSH-Px, glutathione peroxidase; MDA, malondialdehyde; LPO, lipid peroxidation; CAT, catalase; DTCP, Dragon-pearl tea crude polyphenol.
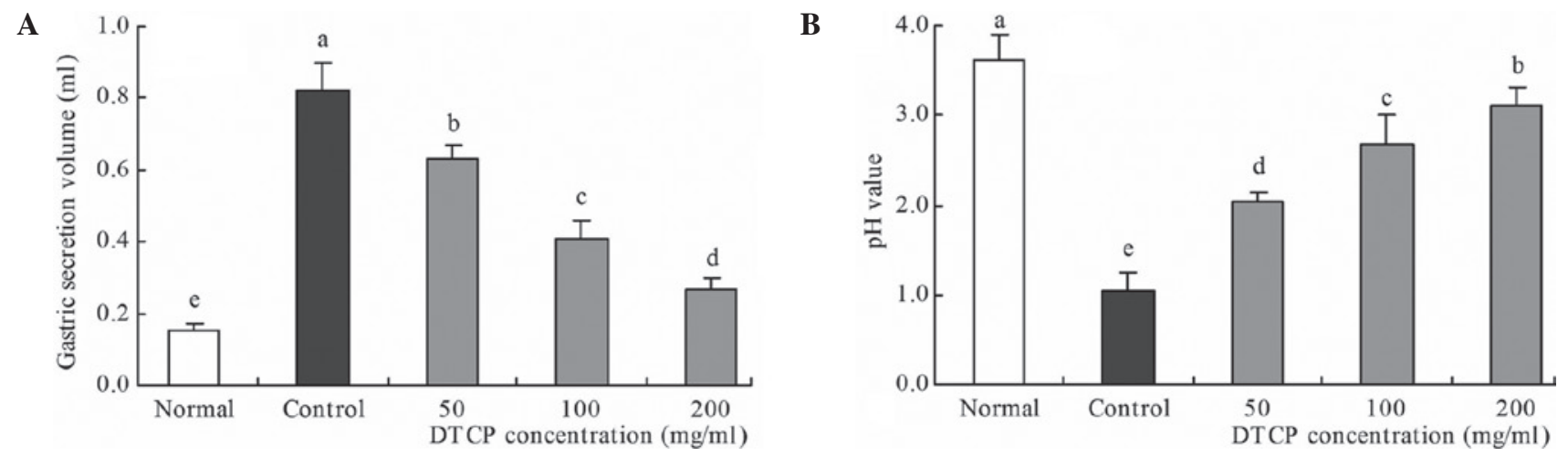

Figure 3. (A) Gastric secretion volume and (B) $\mathrm{pH}$ value of the gastric juice in the reserpine-induced gastric ulcers in mice treated with $\mathrm{DTCP}$. ${ }^{\mathrm{a}-\mathrm{P}} \mathrm{P}<0.05 \mathrm{vs}$. the other groups, according to Duncan's multiple range test. DTCP, Dragon-pearl tea crude polyphenol.

A

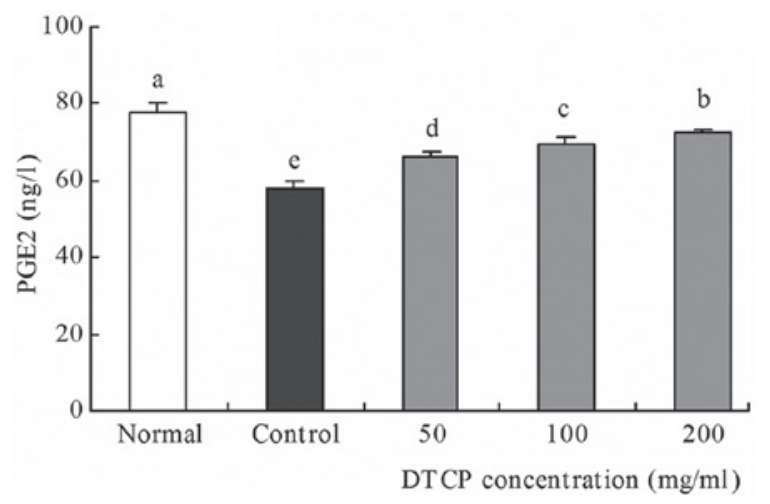

B

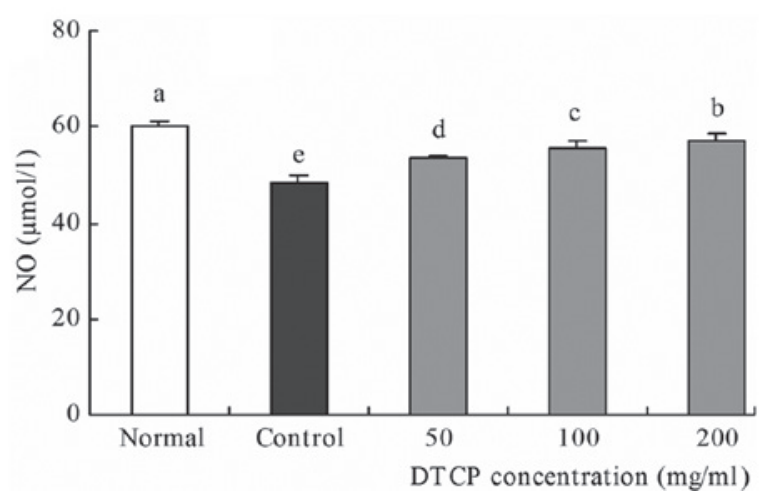

Figure 4. Serum (A) PGE2 and (B) NO levels in the mouse model of reserpine-induced gastric ulcers following treatment with $D T C P$. ${ }^{a-e} P<0.05$ vs. the other groups, according to Duncan's multiple range test. PGE2, prostaglandin E2; NO, nitric oxide; DTCP, Dragon-pearl tea crude polyphenol.

Gastric secretion volume and gastric juice $p H$. In the reserpine-induced gastric ulcer control mice, the highest gastric secretion volume $(0.82 \mathrm{ml})$ and the lowest $\mathrm{pH}$ value (1.04) were observed (Fig. 3). Conversely, the mice in the normal group exhibited the lowest gastric secretion volume $(0.15 \mathrm{ml})$ and the highest $\mathrm{pH}$ value (3.62). DTCP treatment was shown to improve these levels, with the 50, 100 and $200 \mathrm{mg} / \mathrm{kg}$ DTCP-treated mice exhibiting gastric secretion volumes of $0.63,0.41$ and $0.27 \mathrm{ml}$, respectively, and $\mathrm{pH}$ values of $2.03,2.68$ and 3.10 , respectively.
Serum levels of oxidation-associated SOD, GSH-Px, MDA, $L P O$ and CAT. Control group mice presented with the lowest levels of SOD, GSH-Px and CAT, and the highest levels of MDA and LPO (Table I). Mice in the three DTCP treatment groups exhibited increasing levels of SOD, GSH-Px and CAT, and decreasing levels of MDA and LPO levels. The highest concentration of DTCP $(200 \mathrm{mg} / \mathrm{kg})$ produced the maximal change in these levels in the reserpine-induced gastric ulcer mouse model, resulting in levels that were comparable with the normal group mice. 


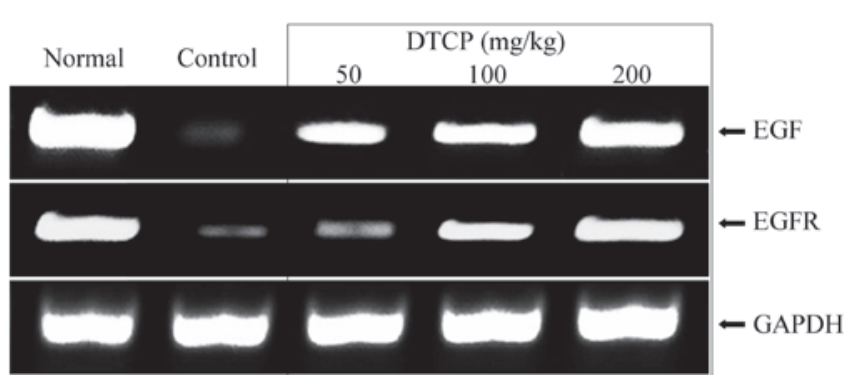

Figure 5. mRNA expression levels of EGF and EGFR in the gastric tissue of mice with reserpine-induced gastric ulcers. DTCP, Dragon-pearl tea crude polyphenol; EGF, epidermal growth factor; EGFR, epidermal growth factor receptor.

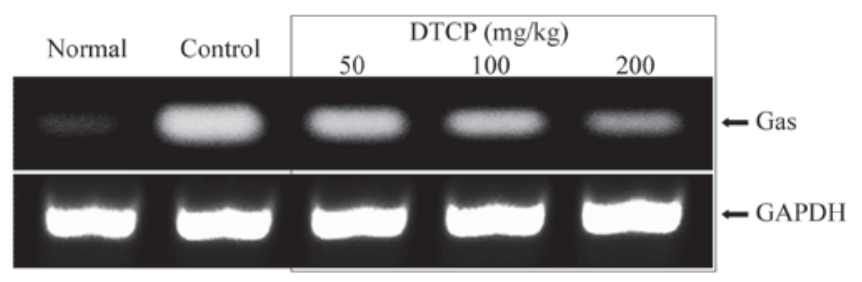

Figure 6. mRNA expression of Gas in the gastric tissue of mice with reserpine-induced gastric ulcers. DTCP, Dragon-pearl tea crude polyphenol; Gas, gastrin.

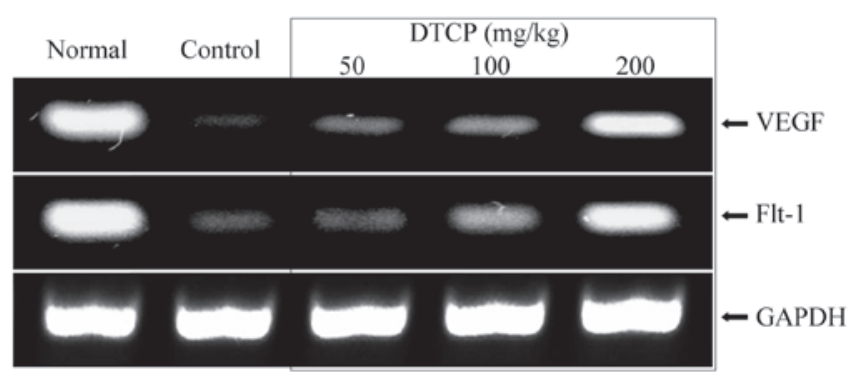

Figure 7. mRNA expression levels of VEGF and Flt-1 in the gastric tissue of mice with reserpine-induced gastric ulcers. DTCP, Dragon-pearl tea crude polyphenol; VEGF, vascular endothelial growth factor; Flt-1, vascular endothelial growth factor receptor 1 .

Serum levels of PGE2 and NO, associated with gastric mucosal protection. Control group mice exhibited the lowest levels of PGE2 and NO, at $57.80 \mathrm{ng} / 1$ and $48.29 \mu \mathrm{mol} / 1$, respectively (Fig. 4). However, treatment with DTCP was demonstrated to increase these levels when compared with the control mice. The 50, 100 and $200 \mathrm{mg} / \mathrm{kg}$ DTCP-treated mice exhibited increasing PGE2 levels of 66.23, 69.38 and $72.65 \mathrm{ng} / 1$, respectively, and increasing NO levels of 53.47 , 55.71 and $57.08 \mu \mathrm{mol} / 1$, respectively. Among the groups, the PGE2 and NO levels were highest in the normal group mice, at $77.86 \mathrm{ng} / 1$ and $60.26 \mu \mathrm{mol} / 1$, respectively.

mRNA expression levels of EGF, EGFR, Gas, VEGF and Flt-1 in the gastric tissue. Expression levels of a number of genes in the gastric tissue of the mice were determined using RT-qPCR. DTCP was demonstrated to alter the mRNA expression levels of EGF, EGFR, Gas, VEGF and Flt-1. DTCP at concentrations of 50,100 and $200 \mathrm{mg} / \mathrm{kg}$ was shown to increase the mRNA expression levels of the epidermal growth-related EGF and
EGFR (Fig. 5) Furthermore, DTCP treatment increased the mRNA expression levels of vascular endothelial growth-related VEGF and Flt-1 (Fig. 6). However, the mRNA expression levels of Gas were reduced in the mice following DTCP treatment at 50,100 and $200 \mathrm{mg} / \mathrm{kg}$ (Fig. 7). The highest concentration of DTCP $(200 \mathrm{mg} / \mathrm{kg})$ exerted the most marked effect, resulting in mRNA expression levels of the various genes that were comparable to those of the normal group mice.

\section{Discussion}

$\mathrm{DPPH}$ and $\mathrm{OH}$ radical assays are important methods for the determination of antioxidant effects in vitro. In the present study, the scavenging activity of DTCP on DPPH and OH radicals was detected, in order to proximately determine the antioxidative capacity of DTCP in vitro (13).

Gastric ulcers are considered to form as a result of an imbalance between agressive and defensive factors. Attack factors include gastric acid, pepsin, H. pylori, drug toxicity and oxygen free radicals. Among these factors, gastric acid and pepsin, which are able to damage the gastric mucosa directly, are the primary attack factors (14). Furthermore, gastric acid may activate the secretion of pepsin, and erode and damage the gastric mucosa. With an increase in the gastric mucosa ulcer index and the secretion of gastric acid and pepsin, the activity of the $\mathrm{H}^{+} / \mathrm{K}^{+}$-ATPase enzyme in the gastric mucosa parietal cells increases, which subsequently activates the stomach cells. In turn, these cells enhance the $\mathrm{H}^{+}$transporting ability of $\mathrm{H}^{+} / \mathrm{K}^{+}$-ATPase; thus, the increased secretion of gastric acid results in excessive gastric acid accumulation and high acidity (15). DTCP may increase the $\mathrm{pH}$ value, reduce gastric injury levels and the gastric juice volume. Therefore, DTCP may be an effective agent for the prevention of gastric ulcers.

Oxygen free radicals are molecules with uncoupled electrons, which are intermediate products in normal biochemical processes. Under normal conditions, free radical metabolites and their removal system maintain a dynamic balance in the process of metabolism (16). SOD and GSH-Px are crucial enzymes for the removal of excess oxygen free radicals in the body, and a reduction in their activity may result in the accumulation of oxygen free radical metabolites (17). MDA is the catabolite from the oxidation of biological membrane polyunsaturated fatty acids by oxygen free radicals. Thus, enhanced levels of MDA indicate increased oxygen free radical metabolites in the body (18). The accumulation of oxygen free radicals in the body results in evident damage to cells, while peptic ulcers have also been associated with the damage induced by oxygen free radicals (19). The activity of SOD and GSH-Px is known to significantly decrease in high altitude areas, while the content of MDA significantly increases (20). As a result, the morbidity of peptic ulcers in high altitude areas is significantly higher compared with that in plain areas (21). In the blood of patients with gastric ulcers, MDA levels are increased significantly; however, the activity levels of SOD and GSH-Px are evidently reduced when compared with that of healthy individuals (22). GSH is considered to be the primary physiological scavenger of free radicals in the gastric mucosa. As free radicals are a key cause underlying the peroxidation of the gastric mucosa to produce LPO, the levels of GSH and LPO in the gastric mucosa are associated and exhibit an evident nega- 
tive correlation (23). CAT is an enzyme scavenger that is able to remove hydrogen peroxide from the body to prevent cells from hydrogen peroxide-induced damage (24). Therefore, the results of the present study indicate that DCPT exerts strong antioxidative effects in vitro and induces effective oxidation resistance in vivo.

PGE2, a crucial factor for cell growth and regulation, is able to stimulate the secretion of $\mathrm{HCO}_{3}{ }^{-}$and increase the content of the gastric mucilage and the flow of mucosal blood, to subsequently enhance the ability of the gastric mucosa to resist damage (25). NO is a key protective factor for the gastric mucosa, and can regulate the secretion of gastric acid, promote the synthesis between the gastric mucus and mucoprotein, maintain and strengthen the mucous barrier function and clear oxygen free radicals (26). Polyphenols in Dragon-pearl tea may increase PGE2 and NO levels in the serum, improve microcirculation in the gastric mucosa, clear oxygen free radicals and strengthen the mucous barrier function.

EGF is an endogenous substance that inhibits the secretion of gastric acid, promotes epithelial proliferation and improves the nutrition into the body to prevent gastric mucosa injury. Furthermore, EGF not only protects the gastric mucosa from damage factors and maintains the intactness of the stomach mucosa, but also stimulates the migration and proliferation of cells to increase the rate of the healing process of gastric ulcers (27). EGFR and EGF exhibit high specificity and affinity. Upon reaching target cells, EGF rapidly binds with EGFR on the cell membrane to regulate cell growth and differentiation (28). A previous study demonstrated that the expression levels of EGF and EGFR are synchronized, which activates the EGF/EGFR system to promote epithelial cell proliferation and tissue-repair on the gastric mucosa, in addition to inhibiting the secretion of gastric acid (29). Excessive gastric acid may be the primary cause of gastric ulcers, and Gas is the primary factor that stimulates the secretion of gastric acid. Exogenous and endogenous Gas can increase the secretion of gastric acid. Therefore, reducing the secretion of Gas may directly decrease the secretion of gastric acid caused by illness, subsequently alleviating gastric ulcers (30). VEGF is one of the most well-studied and potent angiogenic factors with a high specificity, which is able to promote the regeneration of connective tissues and the microvasculature to significantly reduce damage (31). A previous study indicated that VEGF serves a function in the protection of the gastric mucosa and the healing of chronic ulcers (32). VEGF dilutes harmful materials (chemical toxicants and poisonous animalcules) in the stomach to protect the gastric mucosa by increasing the permeability of the microvasculature, and expedites the healing of ulcers by stimulating the generation of glands and angiogenesis. Insufficient levels of Flt-1, a receptor of VEGF, may inhibit the generation of blood vessels in tissues (33). Thus, ulcer healing may be enhanced by increasing the expression of VEGF and Flt-1, to subsequently promote the regeneration of connective tissues, glands and the microvasculature, and dilute the harmful materials in the stomach to protect the gastric mucosa (34). The results of the present study indicate that DTCP may prevent gastric ulcers by increasing the expression levels of EGF, EGFR, VEGF and Flt-1, and reducing the expression of Gas.
In conclusion, the in vitro experiments investigating the antioxidative effects of polyphenols in Dragon-pearl tea indicated that Dragon-pearl tea exerts a notable antioxidative effect in vitro. In addition, animal experiments were conducted to investigate the preventative effect of DTCP on gastric ulcers in vivo. Study into the effect of DTCP on the oxidation state of the damaged gastric tissues and serum in the mice indicated an association between oxidative damage and gastric ulcer formation. Therefore, the polyphenols present in Dragon-pearl tea may be able to mitigate oxidative damage and aid the repair of oxidative-damaged tissues, subsequently preventing and inhibiting the formation of gastric ulcers.

\section{Acknowledgements}

The study was supported by the Program for Innovation Team Building at the Institutions of Higher Education in Chongqing (no. KJTD201325).

\section{References}

1. Su GF, Liang SJ, Dai WZ and Huang JC: The utilization and analyses of nutritive ingredients in Dragon-pearl tea. Guang Xi Shi Fan Da Xue Xue Bao 11: 63-66, 1993 (In Chinese).

2. Sharangi AB: Medicinal and therapeutic potentialities of tea (Camellia sinensis L.) - A review. Food Res Int 42: 529-535, 2009.

3. Benowitz NL: Clinical pharmacology of caffeine. Annu Rev Med 41: 277-288, 1990.

4. Maity S, Vedasiromoni JR and Ganguly DK: Anti-ulcer effect of the hot water extract of black tea (Camellia sinensis). J Ethnopharmacol 46: 167-174, 1995.

5. Correa P, Fontham ET, Bravo JC, Bravo LE, Ruiz B, Zarama G, Realpe JL, Malcom GT, Li D, Johnson WD and Mera R: Chemoprevention of gastric dysplasia: Randomized trial of antioxidant supplements and anti-Helicobacter pylori therapy. J Natl Cancer Inst 92: 1881-1888, 2000.

6. Mu LN, Lu QY, Yu SZ, Jiang QW, Cao W, You NC, Setiawan VW, Zhou XF, Ding BG, Wang RH, et al: Green tea drinking and multigenetic index on the risk of stomach cancer in a Chinese population. Int J Cancer 116: 972-983, 2005.

7. Zhou F, Shen T, Duan T, Xu YY, Khor SC, Li J, Ge J, Zheng YF, Hsu S, DE Stefano J, et al: Antioxidant effects of lipophilic tea polyphenols on diethylnitrosamine/phenobarbital-induced hepatocarcinogenesis in rats. In Vivo 28: 495-503, 2014.

8. Yu X, Xu X and Su J: Protective effects of nanometer selenium on acute gastric mucosal lesion in rats. J Hyg Res 37: 594-586, 2008 (In Chinese).

9. Fu XC, Shan HL, Bai HB and Hu R: Protective effect of Jiangbaiweiyan tablet on ethanol-induced gastric mucosa injury in rats. J Zhejiang Univ (Med Sci) 40: 391-394, 2011 (In Chinese).

10. Wang Q, Zhao X, Qian Y and Wang R: In vitro antioxidative activity of yellow tea and its in vivo preventive effect on gastric injury. Exp Ther Med 6: 423-426, 2013.

11. Li GJ, Sun P, Wang R, Zhou YL, Qian Y and Zhao X: Preventive effect of polysaccharide of Larimichthys crocea swim bladder on reserpine induced gastric ulcer in ICR mice. Korean J Physiol Pharmacol 18: 183-190, 2014

12. Chen S, Zhu K, Wang R and Zhao X: Preventive effect of polysaccharides from the large yellow croaker swim bladder on $\mathrm{HCl} / \mathrm{ethanol}$ induced gastric injury in mice. Exp Ther Med 8: 316-322, 2014.

13. Zhao X, Wang Q, Li GJ, Chen F, Qian Y and Wang R: In vitro antioxidant, anti-mutagenic, anti-cancer and anti-angiogenic effects of Chinese Bowl tea. J Funct Foods 7: 590-598, 2014.

14. Choi SR, Lee SA, Kim YJ, Ok CY, Lee HJ and Hahm KB: Role of heat shock proteins in gastric inflammation and ulcer healing. J Physiol Pharmacol 60 (Suppl 7): 5-17, 2009.

15. Lorentzon P, Bayati A, Lee H and Andersson K: Selective inhibition of the gastric $\mathrm{H}+, \mathrm{K}(+)$-ATPase by omeprazole and related compounds. Ann N Y Acad Sci 834: 592-599, 1997.

16. Valko M, Leibfritz D, Moncol J, Cronin MT, Mazur M and Telser J: Free radicals and antioxidants in normal physiological functions and human disease. Int J Biochem Cell Biol 39: 44-84, 2007. 
17. Li J and Wang Y: Effect of different methods of hypoxic exercise training on free radical oxidation and antioxidant enzyme activity in the rat brain. Biomed Rep 1: 925-929, 2013.

18. Yu GY, Song XF, Liu Y and Sun ZW: Inhaled formaldehyde induces bone marrow toxicity via oxidative stress in exposed mice. Asian Pac J Cancer Prev 15: 5253-5257, 2014.

19. Haggag MS, Elsanhoty RM and Ramadan MF: Impact of dietary oils and fats on lipid peroxidation in liver and blood of albino rats. Asian Pac J Trop Biomed 4: 52-58, 2014.

20. Huang W, Li L, Tian X, Yan J, Yang X, Wang X, Liao G and Qiu G: Astragalus and Paeoniae radix rubra extract inhibits liver fibrosis by modulating the transforming growth factor- $\beta / \mathrm{Smad}$ pathway in rats. Mol Med Rep 11: 805-814, 2015.

21. A XR, Zhang XS and Liu LP: Change of free radicals in levels of machinese in patients with peptic ulcer at medium altitude. Zhongguo Xian Dai Yi Xue Za Zhi 16: 666-668, 2006 (In Chinese).

22. Nagy L, Mózsik G, Vincze A, Süto G, Hunyady B, Rinfel J, Past T and Jávor T: Effects of a novel Hungarian antacid containing Al and $\mathrm{Mg}$ (Tisacid) on mucosal prostaglandin generation and oxygen free radicals in normal rats. Drugs Exp Clin Res 16: 197-203, 1990.

23. Mohan Kumar M, Joshi MC, Prabha T, Dorababu M and Goel RK Effect of plantain banana on gastric ulceration in NIDDM rats: Role of gastric mucosal glycoproteins, cell proliferation, antioxidants and free radicals. Indian J Exp Biol 44: 292-299, 2006.

24. Choi DJ, Kim SL, Choi JW and Park YI: Neuroprotective effects of corn silk maysin via inhibition of $\mathrm{H}_{2} \mathrm{O}_{2}$-induced apoptotic cell death in SK-N-MC cells. Life Sci 109: 57-64, 2014.

25. Demitrack ES, Soleimani $M$ and Montrose MH: Damage to the gastric epithelium activates cellular bicarbonate secretion via SLC26A9 Cl(-)/HCO(3)(-). Am J Physiol Gastrointest Liver Physiol 299: G255-G264, 2010.

26. Li WF, Hao DJ, Fan T, Huang HM, Yao H and Niu XF: Protective effect of chelerythrine against ethanol-induced gastric ulcer in mice. Chem Biol Interact 208: 18-27, 2014.
27. Liu KY, Zhu Y and Huang XZ: Effect of Pongamia pinnata root flavonoids on the quality of ulcer healing and expression of EGF and TGF-alpha in the rat model of gastric ulcer induced by acetic acid. Zhongguo Ying Yong Sheng Li Xue Za Zhi 28: 435-438, 2012 (In Chinese).

28. Alkan Z, Duong FL and Hawkes WC: Selenoprotein W controls epidermal growth factor receptor surface expression, activation and degradation via receptor ubiquitination. Biochim Biophys Acta 1853: 1087-1095, 2015.

29. Cao MB, Dong L, Chang XM, Zou BC and Qin B: Effect of Mexican tea herb and pilular adina herb on concrescence of gastric mucosa in experimental gastric ulcer rats. Chin J Integr Med 13: 132-136, 2007.

30. Dai R, Xu JY, Che MS, Chen HZ, Zhang L, Zhou J and Xu L: Effects of somatostatin on the serum and gastric gastrin in pancreatogenous ulcer. Lin Chuang Jun Yi Za Zhi 24: 4-7, 1996 (In Chinese)

31. Chung R, Foster BK and Xian CJ: The potential role of VEGF-induced vascularisation in the bony repair of injured growth plate cartilage. J Endocrinol 221: 63-75, 2014.

32. Moraes TM, Rozza AL, Kushima H, Pellizzon CH, Rocha LR and Hiruma-Lima CA: Healing actions of essential oils from Citrus aurantium and d-limonene in the gastric mucosa: The roles of VEGF, PCNA and COX-2 in cell proliferation. J Med Food 16: 1162-1167, 2013.

33. Khomeriki SG and Zhukov AG: Morphological features of the gastric mucosa capillary network in patients with portal hypertension. Arkh Patol 73: 43-47, 2011 (In Russian).

34. Akimoto M, Hashimoto H, Maeda A, Shigemoto M and Yamashita K: Roles of angiogenic factors and endothelin-1 in gastric ulcer healing. Clin Sci (Lond) 103 (Suppl 48): 450S-454S, 2002 . 